\title{
Rola białka RIPK4 w fizjologii naskórka
}

\section{mgr Ewelina Madej, \\ mgr Anna Lisek, \\ dr hab. Agnieszka Wolnicka- -Głubisz, prof. UJ ${ }^{\square}$}

Zakład Biofizyki, Wydział Biochemii, Biofizyki i Biotechnologii, Uniwersytet Jagielloński w Krakowie

https://doi.org/10.18388/pb.2021_370

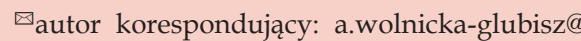
uj.edu.pl

Słowa kluczowe: RIPK4; naskórek; różnicowanie; stan zapalny

Wykaz skrótów: BPS (ang. Bartsocas-Papas Syndrome) - zespół Bartsocas-Papas; CHAND (ang. Curly Hair-Ankyloblepharon-Nail Dysplasia) - zespół kręte włosy - zrośniete powieki- dysplastyczne paznokcie; IKK (ang. I $K B$ kinase) - kinaza IкB; IL17 (ang. Interleukin 17) - Interleukina 17; IRF6 (ang. Interferon Regulatory Factor 6) - czynnik regulujący interferon 6; IKB (ang. Inhibitor of nuclear factor kappa B) - inhibitor czynnika jądrowego kappa B; JNK (ang. c-Jun N-terminal Kinase) - kinaza białka c-Jun; NF-kB (ang. Nuclear Factor kappa B) - jądrowy czynnik transkrypcyjny kappa B; NLS (ang. Nuclear Localization Signal) - sygnał lokalizacji jadrowej; PKC (ang. Protein Kinase C) - kinaza białkowa C; PKC-1 $\beta$ (ang. Protein Kinase C-like $1 \beta$ ) - kinaza białkowa C-1 ; PKK (ang. Protein Kinase C-associated Kinase) - kinaza związana z PKC; PKP1 (ang. Plakophilin 1) - plakofilina 1; PMA (ang. Phorbol 12-Myristate 13 Acetate) - ester forbolu; PPS (ang. Popliteal Pterygium Syndrome) - zespół mnogich płetwistości typu Aslana; RIPK (ang. Receptor Interacting Protein Kinases) - oddziałujące $\mathrm{z}$ receptorem kinazy serynowo-treoninowo-białkowe; SCC (ang. Squamous Cell Carcinoma) - rak kolczystokomórkowy; STAT (ang. Signal Transducer and Activator of Transcription) - białka przekazujące sygnał i aktywujące transkrypcję; TLR (ang. Toll-like Receptors) - receptory Toll-podobne; TNFR-1 (ang. Tumor Necrosis Factor Receptor 1) - receptor czynnika martwicy nowotworów 1; TNFa (ang. Tumor Necrosis Factor a) - czynnik martwicy mowotworów a; TRAF (ang. TNF Receptor Associated Factor) - czynnik aktywujący zależny od TNF

Podziekowania: Praca powstała $\mathrm{w}$ ramach realizacji grantu OPUS $\mathrm{nr}$ 2018/31/B/ NZ5/01423 oraz PRELUDIUM nr 2018/31/N/ NZ3/02625 finansowanych ze środków przyznanych przez Narodowe Centrum Nauki.

\section{STRESZCZENIE}

B ałka regulujące morfogenezę naskórka zapewniają jego prawidłową budowę oraz funkcję. Mutacje w ich obrębie prowadzą do licznych zaburzeń $w$ pełnionej funkcji. Jednym $\mathrm{z}$ takich ostatnio opisanych białek jest kinaza białkowa oddziałująca $\mathrm{z}$ receptorem kinaz serynowo-treoninowych 4 (RIPK4). Kinaza ta w naskórku pełni ważną funkcję regulatora homeostazy pomiędzy proliferacją a różnicowaniem się keratynocytów. Mutacje w obrębie genu kodującego białko RIPK4 skutkują u ludzi letalnym zespołem Bartsocas-Papas lub zespołem mnogich płetwistości typu Aslana, a jego delecja u myszy (Ripk4 ${ }^{-/}$) prowadzi do przedwczesnej śmierci noworodków spowodowanej licznymi zrostami skórnymi. RIPK4 odgrywa rolę $\mathrm{w}$ stanie zapalnym skóry. Sugeruje się, że białko to $\mathrm{w}$ skórze pełni rolę supresora nowotworów, ponieważ jego poziom zmniejsza się $w$ rakach kolczystokomórkowych względem skóry zdrowej, a jego indukowana delecja w modelu mysim sprzyja powstawaniu i rozrostowi brodawczaków i raków kolczystokomórkowych wywoływanych na drodze chemicznej. W pracy omówiono rodzinę białek RIP, udział białka RIPK4 w różnicowaniu się naskórka i szlakach sygnalizacyjnych, a także konsekwencje zaburzeń wywołanych jego nieprawidłową ekspresją.

\section{WSTĘP}

Skóra (łac. cutis, gr. derma) jest największym narządem człowieka pełniącym wiele istotnych funkcji w tym przede wszystkim ochronną, stanowiąc zewnętrzną powłokę ciała. Funkcję bariery i ochrony przed różnymi czynnikami zewnętrznymi pełni przede wszystkim warstwa rogowa naskórka zbudowana z korneocytów, czyli przekształconych keratynocytów oraz naturalnego czynnika nawilżającego (NMF) i płaszcza hydrolipidowego. Keratynocyty stanowią główny typ komórek naskórka (95-98\% wszystkich komórek), biorą udział w utrzymaniu bariery naskórkowej i w procesach immunologicznych. Różnicowanie się keratynocytów jest procesem złożonym, w który zaangażowanych jest wiele białek, zapewniając prawidłową budowę i funkcje naskórka oraz jej wytworów. Jednym z ważnych regulatorów morfogenezy naskórka w rozwoju embrionalnym jest kinaza oddziaływująca z receptorem RIPK4, należąca do rodziny kinaz RIP [1].

\section{RODZINA BIAŁEK RIP}

Rodzina oddziałujących z receptorem kinaz serynowo-treoninowych, a także tyrozynowej RIPK obejmuje siedem białek (RIPK1-RIPK7), które cechuje posiadanie konserwatywnej domeny kinazowej oraz unikalnych domen funkcjonalnych [2]. Kinazy RIP nie tylko wykazują podobieństwo $w$ budowie, ale mają także wspólne cechy funkcjonalne. Każda z tych kinaz odgrywa istotną rolę w sytuacjach stresu komórkowego, integrując zarówno pozakomórkowe sygnały stresu przekazywane przez różne receptory na powierzchni komórki, jak i sygnały stresu wewnątrzkomórkowego. Aktywność tych kinaz obserwuje się w sytuacjach stresowych spowodowanych między innymi przez infekcje patogenami, stan zapalny, różnicowanie się komórek czy uszkodzenie nici DNA. Pomimo różnorodności bodźców kinazy RIP prowadzą do odpowiedzi sprzyjającej przeżyciu komórek oraz odpowiedzi zapalnej poprzez aktywowanie czynników transkrypcyjnych jak jądrowy czynnik transkrypcyjny kappa B (NF-kB) i białko aktywujące 1 (AP-1), ale także mogą kierować komórki na drogę śmierci. Uważa się, że kinazy RIP są kluczowymi regulatorami przeżycia oraz śmierci komórek [3].

Kinaza RIP1 została pierwotnie opisana jako adaptor molekularny prowadzący do śmierci komórki poprzez oddziaływanie z antygenem Fas/APO1 (CD95). Kolejne badania wykazały jednak, że brak RIPK1 w komórkach nie wpływa znacząco na proces apoptozy poprzez szlak Fas/APO1, za to zahamowana zostaje aktywacja szlaku NF-kB indukowana przez czynnik martwicy 
nowotworów a (TNFa) [2]. RIPK1 jest częścią dwóch kompleksów zaangażowanych $\mathrm{w}$ aktywację NF-kB poprzez receptor czynnika martwicy nowotworów 1 (TNFR-1). Kompleks I składający się z receptorów TNFR1, TRAF2, RIP1, receptora TNF związanego $\mathrm{z}$ domeną śmierci (TRADD) oraz c-IAP1 prowadzi do aktywacji NF-kB, natomiast $\mathrm{w}$ przypadku niewystarczającej wydajności tego procesu aktywowany jest kompleks II, który składa się z TRADD, RIPK1, FADD, prokaspazy 8 oraz kaspazy 10 i inicjuje apoptozę [4]. Elementem strukturalnym, dzięki któremu RIPK1 oddziałuje zarówno w szlaku sygnalizacyjnym Fas/APO1 (CD95) jak i zależną od TNFa aktywację NFкB jest znajdująca się na C-końcu domena śmierci (DD). Umożliwia ona oddziaływanie $\mathrm{z}$ innymi białkami zawierającymi tą domenę, takimi jak receptor TNFR1 i Fas czy białka adaptorowe TRADD i FADD. Kolejnymi opisanymi członkami rodziny białek RIP były RIPK2 i RIPK3.

Kinaza RIP2 charakteryzuje się obecnością na C-końcu domeny rekrutacji kaspazy (CARD) aktywującej i rekrutującej kaspazy, która jest elementem decydującym o apoptotycznych właściwościach tego białka [2,4]. Bierze ono również udział w regulacji aktywacji czynnika transkrypcyjnego NF-kB. RIPK2 ulega wiązaniu i ubikwitylacji przez inhibitor apoptozy sprzężony z chromosomem X (XIAP), dzięki czemu wchodzi w interakcje z NOD1 i NOD2 poprzez obecne w nich domeny CARD [5]. Domena kinazowa RIPK2 jest również niezbędnym elementem strukturalnym do przekazu sygnału i aktywacji NF-kB poprzez NOD1 i NOD2 [4].

RIPK3 poza homologiczną domeną kinazową białek RIP posiada również unikalną dla siebie domenę C-końcową, która nie wykazuje homologii do innych znanych domen apoptotycznych. W jej obrębie zidentyfikowano homotypowy motyw interakcji RIP (RHIM), który umożliwia interakcję RIPK3 z RIPK1 i hamowanie zależnej od TNFa aktywacji NF-кB. Kompleks RIPK3-RIPK1 stanowi również mediator procesu programowanej nekrozy [6].

Kinaza RIP4 została opisana po raz pierwszy w 2000 roku jako oddziałujące z kinazą białkową C - delta (PKC- $\delta$ ) białko DIK (ang. PKC- $\delta$ interacting protein kinase). Ortolog białka występujący u myszy oddziałuje z kinazą białkową C - beta (PKC- $\beta$ ) i otrzymał nazwę kinazy zasocjowanej z kinazą białkowa C (PKK). Ze względu na występującą w białku DIK/PKK N-końcową domenę kinazową, która wykazuje homologię względem uprzednio zidentyfikowanych białek z rodziny RIP, do użytku weszła nazwa RIPK4 [4]. W strukturze kinazy można wyróżnić również domenę pośrednią o niepoznanej funkcji oraz 11 powtórzeń ankirynowych na C-końcu (Ryc. 1) [7].

Odkryte zostały również kinazy RIP5, RIP6 i RIP7, jednakże ich funkcje biologiczne nie zostały dotychczas scharakteryzowane. Kinaza SgK288 otrzymała nazwę RIP5 dzięki znaczącemu podobieństwu strukturalnemu do RIPK4. Ma nie tylko homologiczną domenę kinazową na N-końcu, ale również powtórzenia ankirynowe na C-końcu, stąd podejrzewa się również podobieństwa $\mathrm{w}$ pełnionych przez oba białka funkcjach [3]. RIP6 i RIP7 zawierają motyw powtórzeń bogatych w leucynę (LRR) i znane są jako kinazy

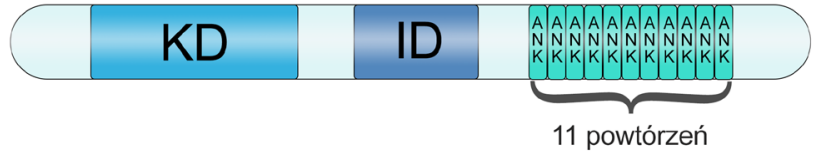

Rycina 1. Schemat przedstawiający budowę strukturalną kinazy RIPK4. KD - domena kinazowa, ID - domena pośrednia, ANK - powtórzenia ankirynowe.

bogate w powtórzenia leucynowe LRRK1 i LRRK2 [3]. W ich strukturze można wyróżnić domenę Ras złożonych białek/C-koniec Roc (Roc/COR), powtórzenia ankirynowe oraz motyw WD40 (RIPK7). RIPK7 zostało rozpoznane jako istotne białko w patogenezie chorób neurodegeneracyjnych, przede wszystkim w chorobie Parkinsona [8].

\section{RIPK4 W RÓŻNICOWANIU SIE NASKÓRKA (KERATYNOCYTÓW)}

Pierwsze doniesienia na temat funkcji RIPK4 pochodzą z badań nad myszami z delacją genu ripk4. Okazało się, że u myszy Ripk4 $4^{-/-}$naskórek pozbawiony jest warstwy rogowej, a zamiast niego występuje gruba warstwa płaskich parakeratotycznych komórek (zawierającymi jądra komórkowe). Ponadto naskórek cechuje hiperplazja warstwy kolczystej i ziarnistej, co sprawia, że jego funkcje ochronne są poważnie zaburzone $[9,10]$. Co ciekawe, heterozygotyczne myszy Ripk $4^{+/-}$fenotypowo nie różnią się od myszy dzikich Ripk $4^{+/+}$. Delecja genu ripk4 jest letalna, ponieważ myszy Ripk $4^{/-}$umierały $\mathrm{w}$ ciągu godziny po porodzie $\mathrm{w}$ wyniku uduszenia wywołanego licznymi zaburzeniami w budowie skóry i zrostami wszystkich zewnętrznych otworów [9,11]. Jak wykazał De Groote i wsp. przyczyną zrostów jest występowanie ektopowej ekspresji E-kadheryny, która sprawia, że przylegające nabłonki zbudowane $\mathrm{z}$ atypowych keratynocytów ulegają fuzji [9]. Dowodem na to są badania Urwyler-Rösselet i wsp., która wprowadzając specyficzną dla keratynocytów delecję E-kadheryny u myszy Ripk4\%potwierdziła, że proces zrostu ogona do ciała czy zrośnięcia się otworu gębowego u tych myszy można odwrócić [12]. Kolejne dowody wskazujące na udział Ripk4 w procesie różnicowania się keratynocytów potwierdzają badania grupy Adams i wsp., którzy wykazali, że uszkodzenie skóry u myszy skutkuje natychmiastowym spadkiem poziomu ekspresji białka Ripk4, utrzymujący się aż do całkowitego zagojenia się rany (ok. 14 dni), a obniżeniu ekspresji Ripk4 towarzyszy wzrost poziomu Ripk3. W mysiej skórze poziom ekspresji białka Ripk4 w naskórku i mieszkach włosowych jest wysoki. Ci sami badacze wykazali również, że czynniki wzrostu (EGF, TGF $\beta$ ), jak i cytokiny (TNFa lub IL1 $\beta$ ) oraz ester forbolu (PMA) prowadzą do obniżenia poziomu RIPK4 w ludzkich keratynocytach HaCaT in vitro. Natomiast deksametazon - steroid hamujaccy proliferacje keratynocytów nieznacznie zwiększa poziom ekspresji RIPK4 podobnie jak kwas all-trans retinowy (witamina A), co sugeruje, że RIPK4 reguluje równowagę między proliferacją a różnicowaniem się keratynocytów [1]. Ponadto badania nad wpływem PMA, aktywatora kinazy białkowej C-1 $\beta$ (PKC-1 $\beta$ ) na poziom ekspresji RIPK4 zwróciły uwage, na fakt, iż gen ten może być regulowany przez ścieżkę PKC. Kinaza PKC-1 $\beta$ aktywowana jest przez jony wapnia, które stanowią kluczowy czynnik sygnałowy w różnicowaniu się 
keratynocytów. Aktywowany PKC promuje różnicowanie keratynocytów poprzez indukowanie ekspresji różnych genów związanych z tym procesem. Wykazanie, że kinaza RIPK4 oddziałuje z białkową kinazą C, stanowiło podstawę do poznania molekularnych mechanizmów zaangażowania RIPK4 w tym procesie [10]. I faktycznie, obniżenie poziomu RIPK4 przez siRNA powoduje wzrost poziomu inhibitora czynnika jądrowego kappa B (IkBa), wykazując po raz kolejny, że RIPK4 prowadzi do aktywacji szlaku NF-kB [13]. Choć autorzy nie wykazali zmian w tempie proliferacji komórek, to potwierdzili wzrost poziomu ekspresji keratyny 10, markera różnicowania się keratynocytów. Co ciekawe, inne badania wskazują na bezpośrednie odziaływanie kinazy RIPK4 z keratyną 14, która należy do białek filamentów pośrednich charakterystycznych dla keratynocytów warstwy podstawnej skóry. Keratyna 14 jest zaangażowana w tworzenie się desmosomów poprzez oddziaływanie z plakofiliną 1 (PKP1), co jest istotne dla procesu różnicowania się keratynocytów [14]. Jak wykazały badania, białko PKP1 jest fosforylowane przez kinazę RIPK4 [15]. Dalsze badania nad mechanizmem regulacji różnicowania keratynocytów przez RIPK4 wykazały także, że kinaza ta może bezpośrednio aktywować czynnik regulujący interferon 6 (IRF6) oraz indukować jego translokacje do jądra [16]. IRF6 jest czynnikiem transkrypcyjnym, co oznacza, że wiąże się w specyficznych regionach DNA i pomaga $\mathrm{w}$ kontrolowaniu aktywności określonych genów. Białko to reguluje transkrypcje genów kodujących białka istotne w procesie różnicowania w tym czynnik transkrypcyjny GRHL3 oraz czynnik OVOL1, który hamuje transkrypcję genów promujących proliferację jak c-Myc. Ponad to, wykazano, że kinaza RIPK4 wraz z czynnikiem IRF6 regulują stan zapalny poprzez przekaz sygnału szlakiem kinazy PKC prowadząc do ekspresji cytokin CCL5 oraz CXCL1 [29] Dane z analizy transkryptomu (RNA-seq) pokazują, że aktywacja IRF6 może odbywać się zarówno w sposób zależny, jak i niezależny od RIPK4. Spektroskopia mas potwierdziła, że RIPK4 fosforyluje IRF6 na Ser413 i Ser424, ale także wyzkazała nowe miejsce fosforylacji Ser90. W pierwszej kolejności fosforylowane są reszty Ser413 i Ser424, które wzmacniają fosforylację na Ser90 przez RIPK4. Dodatkowo analiza transkryptomu wykazała zmiany w genach kodujących białka związane z metabolizmem lipidów i ścisłych połączeń między komórkowych [17]. Zmutowane białko RIPK4 hamuje aktywność IRF6 oraz nie może tworzyć z nim kompleksów. Skutkiem tego jest brak procesu różnicowania się keratynocytów. Jedna z takich mutacji zmiany sensu (missensownych mutacji) w domenie kinazowej RIPK4 (pIle121Asn) została zidentyfikowana w zespole płetwistości podkolanowych Bartsocas-Papas (BPS), charakteryzującego się występowaniem nieprawidłowości czaszkowo-twarzowych, kończynowych oraz narządów płciowych $[10,16]$. Natomiast De Groote i wsp. wykazał, że RIPK4 znajduje się za IRF6, dlatego to IRF6 reguluje ekspresje RIPK4 w Xenopus oraz, że gastrulacja zależna od IRF6 zachodzi częściowo poprzez regulację ekspresji kinazy RIPK4, która w tym procesie reguluje F-aktynę [9].

\section{ZESPOŁY ZWIĄZANE Z MUTACJĄ W GENIE RIPK4}

Ze względu na udział kinazy RIPK4 w procesie różnicowania się keratynocytów mutacje $\mathrm{w}$ genie prowadzące do syntezy nieprawidłowego białka mogą skutkować w nie- prawidłowym formowaniu się naskórka [10]. Gen RIPK4 kodujący białko RIPK4 zlokalizowany jest na chromosomie 21q22.3. Mutacje w obrębie domeny kinazowej białka RIPK4 u ludzi występują w letalnym zespole BPS, opisany powyżej $[18,19]$, a także w jego wariancie zespole mnogich płetwistości typu Aslana (PPS) [19], czy zespole CHAND (ang. Curly Hair-Ankyloblepharon-Nail Dysplasia) charakteryzującego się krętymi włosami, zrośnięciem powiek i dysplazją paznokci [20]. Zespoły te dziedziczone są w sposób autosomalny, recesywny i charakteryzują się poważnymi zaburzeniami w budowie skóry takimi jak zrosty naskórkowe, deformacje twarzy i ust, rozczepieniem podniebienia i pterygią. Najpoważniejszym schorzeniem jest BPS, który został opisany przez Bartsocas i Papas w 1972 roku. Jest to schorzenie letalne o bardzo złym rokowaniu, najdłuższy opisany czas przeżycia dziecka z tym zespołem wad wyniósł 20 miesięcy [21]. Analizy sekwencjonowania egzonów genu kodującego RIPK4 wykazały, że w przypadku PBS dochodzi do mutacji w reszcie aminokwasowej w pozycji 81, prowadzącej do zamiany aminokwasu izoleucyny na asparaginę $w$ domenie kinazowej tego białka. Reszta ta jest wysoce konserwatywna, a mutacja ta pozbawia białko aktywności [18]. Niezależna grupa badawcza także wykazała obecność mutacji w genie RIPK4 w przypadku PBS z tym wyjątkiem, że mutacje zaobserwowano w pozycji aminokwasu 121 (Ile121Asn) oraz 184 (Thr184Ile) jednak obie w obrębie domeny kinazowej [19]. Łagodniejszą odmianą naskórkowej dysplazji jest zespół CHAND spowodowany mutacją c850 G > A w egzonie 6 powodująca zmianę Glu 248 Lys w domenie kinazowej RIPK4, co uniemożliwia utworzenie aktywnej formy białka, jaką jest homodimer RIPK4 [20]. Badania dzieci z PPS oraz z BPS wskazują, że mutacje w RIPK4 mogą nasilać cechy fenotypowe tych ektodermalnych dysplazji wzdłuż spektrum PPS-BPS [22].

\section{ROLA RIPK4 W STANIE ZAPALNYM SKÓRY}

Stan zapalny pojawia się $\mathrm{w}$ organizmie $\mathrm{w}$ odpowiedzi na szkodliwe dla zdrowia czynniki takie jak drobnoustroje chorobotwórcze, promieniowanie, substancje chemiczne lub przerwanie ciągłości tkanek. Charakteryzuje się zwiększoną aktywacją komórek układu odpornościowego, w tym komórek tucznych, makrofagów tkankowych i neutrofili, które odpowiadają za produkcję mediatorów stanu zapalnego. Zalicza się do nich cytokiny, chemokiny, aktywne aminy, peptydy oraz mediatory lipidowe [23]. Za aktywowanie odpowiedzi zapalnej odpowiadają receptory rozpoznające wzorce (PRR), do których należą między innymi receptory toll-podobne (TLR), receptory lektynowe typu C (CLR) czy receptory NOD-podobne (NLR) [23]. Receptory PRR oddziałują z wzorcami molekularnymi związanymi z patogenami (PAMP) lub z powstającymi endogennie wzorcami molekularnymi związanymi z uszkodzeniem (DAMP), co prowadzi do aktywacji szlaków sygnalizacyjnych regulujących ekspresję mediatorów pro- i przeciwzapalnych. Kinazy z rodziny RIP, w tym RIPK4, pełnią rolę białek adaptorowych wspomagających transdukcje sygnału ścieżkami aktywowanymi w procesach zapalnych, w tym $\mathrm{w}$ szlaku NF-kB a także JNK/STAT [6], co przedstawia Ryc. 2. Czynnik NF-kB jest jednym z najważniejszych czynników transkrypcyjnych, który odpowiada za regulację ekspresji wielu genów kodujących różnorodne białka, w tym cytokin 
i chemokin $\mathrm{w}$ czasie odpowiedzi zapalnej. $\mathrm{W}$ formie nieaktywnej NF-kB w cytoplazmie jest związany z białkiem inhibitorowym IkB-który maskuje jego sekwencje lokalizacji jądrowej (NLS). Aktywacja ścieżki NF-kB może zachodzić na drodze klasycznej (kanonicznej), jak i alternatywnej. W przypadku klasycznej drogi aktywny kompleks kinaz inhibitorów кB (IKK) składający się z dwóch podjednostek katalitycznych IKKa i IKK $\beta$ oraz podjednostki regulatorowej IKKY (znanej również jako NEMO) [24] bezpośrednio fosforyluje inhibitor ІкB. Fosforylacja ta prowadzi do jego degradacji $\mathrm{w}$ proteasomie, a tym samym odsłonięcia sekwencji NLS czynnika NF-kB, który następnie ulega translokacji do jądra komórkowego.

Jak wykazały liczne badania białko RIPK4 wspomagania oddziaływanie między podjednostkami IKKa i IKK $\beta$ oraz prowadzi do ich aktywacji poprzez fosforylację IKKa na resztach Ser176/180, oraz IKK $\beta$ na resztach Ser177/181 stabilizując cały kompleks IKK, a tym samym zwiększając jego efektywność $[13,25]$. Co ciekawe kinaza RIPK4 może uczestniczyć w aktywacji ścieżki NF-kB zarówno na drodze klasycznej, jak i alternatywnej [13]. Zaprojektowanie mutanta punktowego RIPK4 o zmniejszonej aktywności domeny kinazowej pozwoliło wykazać, że domena ta jest niezbędna i wystarczająca, aby białko mogło aktywować szlak NF-kB. Z kolei występujące na C-końcu powtórzenia ankirynowe poprzez wewnątrzcząsteczkowe interakcje mogą prowadzić do zahamowania aktywności domeny kinazowej RIPK4, wywierając dominujący negatywny efekt na jej zdolność do aktywacji czynnika NF-kB $[7,10]$. Badania na keratyno- cytach, również potwierdzają powyższe doniesienia [1,11]. W modelu mysim wykazano, że myszy ze specyficzną co do miejsca nadekspresją Ripk4 w skórze (k14-Ripk4) wykazują znacznie szybszy i intensywniejszy odczyn zapalny $\mathrm{w}$ odpowiedzi na ester forbolu, który utrzymuje się dłużej w porównaniu do myszy kontrolnych. Pomimo wzmożonej odpowiedzi, stan zapalny ma przebieg prawidłowy, który z biegiem czasu mija. Chroniczny stan zapalny jest jednym z czynników promujących nowotworzenie, dlatego tym bardziej zaskakujące są obserwacje wskazujące, że nadekspresja RIPK4 nie zwiększa tempa pojawiania się indukowanych przez PMA guzów [11]. Jak wykazano później, to spadek ekspresji RIPK4 przyczynia się do rozwoju nie melanotycznych nowotworów skóry w tym raka kolczytokomórkowego [26].

Stan zapalny jest procesem wyjątkowo złożonym, będącym pod kontrolą wielu szlaków sygnalizacyjnych. Oprócz szlaku NF-kB istotne znaczenie ma przekaz sygnału drogą JAK/STAT. Kinazy białka c-Jun (JNK) zwane inaczej kinazami aktywowanymi stresem (SAPK) należą do rodziny kinaz aktywowanych mitogenem (MAPK). Uczestniczą one w transdukcji sygnału po aktywacji receptorów przez cytokiny typu I/II. Kinazy JNK fosforylują i aktywują przekaźniki sygnału i aktywatory transkrypcji (STAT) regulujące ekspresję cytokin [27], rycina 2. Wykazano także, że kinazy te ulegają aktywacji między innymi po stymulacji komórek TNF-a, co prowadzi do transkrypcji genów zależnych od AP-1 oraz aktywacji ścieżki NF-kB [23]. Kinaza RIPK4 prawdopodobnie jest zaangażowana w akty-

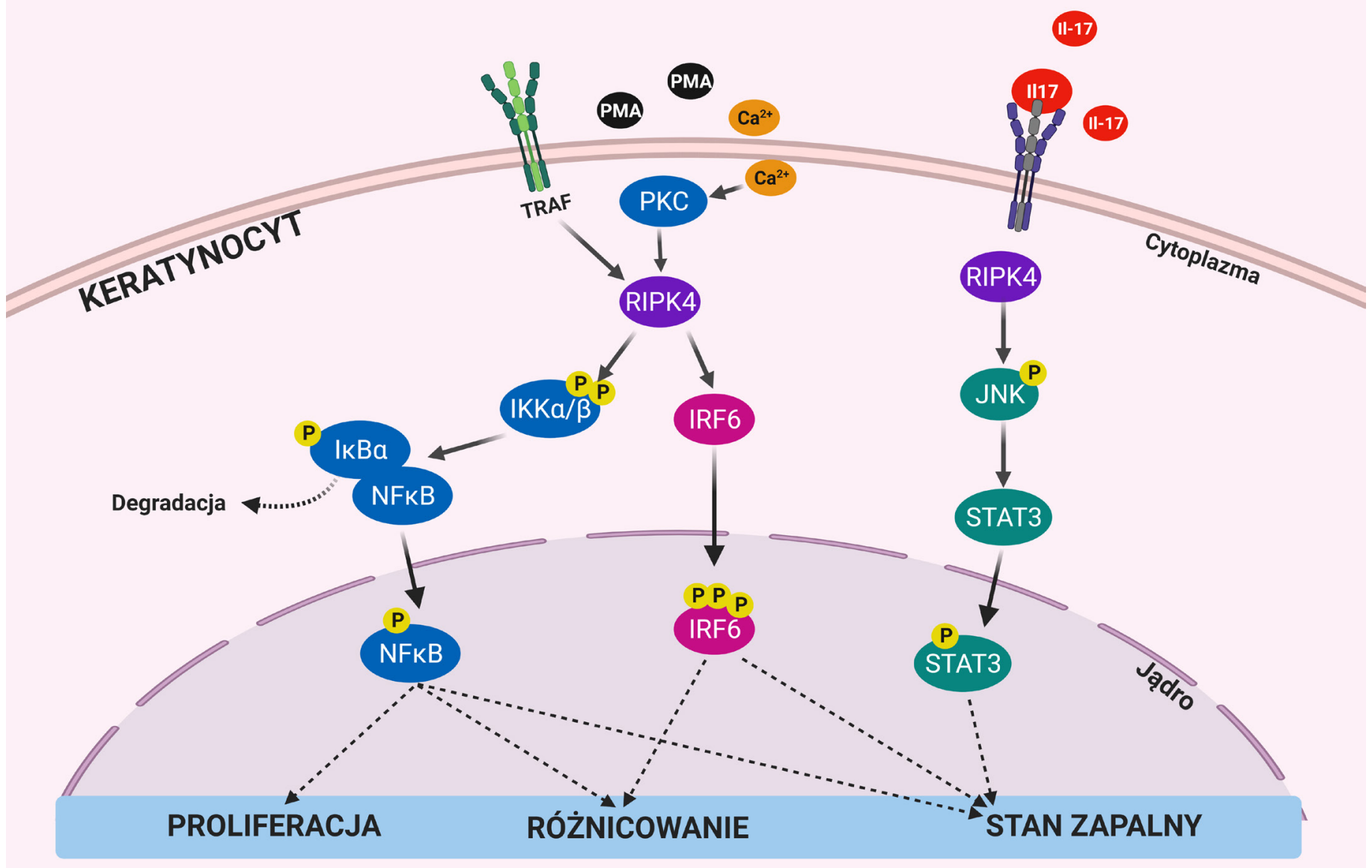

Rycina 2. Schemat zaangażowania RIPK4 w szlaki sygnalizacyjne regulujące różnicowanie, proliferację i stan zapalny w skórze. 
wację kinazy JNK [18]. Badania na keratynocytach wykazały, że stymulowanie komórek interleukiną 17 (IL17) powoduje wzrost ekspresji RIPK4, który z kolei prowadzi do aktywacji czynnika transkrypcyjnego STAT3 indukującego ekspresje chemokin takich jak CCL20, CXCL1, CXCL2, CXCL8, CXCL10, przy czym najwyższy wzrost obserwuje się dla CCL20 $[28,29]$. Prawdopodobnie kinaza RIPK4 może fizycznie i funkcjonalnie oddziaływać rodziną białek adaptorowych zależnych od TNF (TRAF), które również prowadzą do aktywacji ścieżki sygnalnej NFKB czy JNK. RIPK4 stabilizuje m.in. TRAF2 poprzez promowanie jego ubikwitynacji $\mathrm{w}$ procesie aktywacji NF-KB indukowanej TNFa [30].

\section{ŁUSZCZYCA A RIPK4}

Łuszczyca (łac. psoriasis) to przewlekła, nawracająca choroba skóry uwarunkowana genetycznie o dziedziczeniu wielogenowym. Charakteryzuje się nadmierną i niekontrolowaną proliferacją komórek naskórka, a także akantozą i parakeratozą. Choroba ta jest częstą przyczyną problemów dermatologicznych - dotyczy ok $2 \%$ populacji zachodniej ze zmienną częstością występowania w zależności od grup etnicznych [31]. Łuszczyca jest schorzeniem należącym do chorób o podłożu autoimmunizacyjnym, w której pośredniczą limfocyty $\mathrm{T}$ i wydzielane przez nie cytokiny. Istotna role $\mathrm{w}$ regulacji wydzielania i ekspresji prozapalnych cytokin i czynników wzrostu pełni czynnik transkrypcyjny NF-kB, co ma istotne znaczenie $\mathrm{w}$ patogenezie i rozwoju łuszczycy [32], podobnie jak chemokina CCL20 i IL17 oraz czynnik transkrypcyjny STAT3, które ulegają zwiększonej ekspresji w skórnych zmianach łuszczycowych. Jak już wspomniano wcześniej, kinaza RIPK4 odgrywa szczególną rolę w transdukcji sygnału szlakiem NF-kB, oraz uczestniczy w aktywacji czynnika transkrypcyjnego STAT3 prowadzącego do ekspresji chemokiny CCL20 po stymulacji komórek IL-17. Dodatkowo badania histopatologiczne biopsji skóry pacjentów z łuszczycą potwierdzają znacznie wyższy poziom ekspresji białka RIPK4 w porównaniu do poziomu w zdrowej, prawidłowej skórze [28].

\section{RIPK4 I CHOROBY AUTOIMMUNOLOGICZNE}

Zaburzenia autoimmunologiczne rozwijają się w wyniku utraty tolerancji układu odpornościowego wobec antygenów własnych, co prowadzi do niszczenia tkanek organizmu. Choroby z tej grupy mogą być wielonarządowe lub ograniczać się do specyficznych organów.

Regulacja szlaku sygnalizacyjnego NF-kB przez kinazę RIPK4 ma istotne znaczenie $\mathrm{w}$ patogenezie tocznia rumieniowatego układowego (łac. lupus erythematosus systemicus). Jest to autoimmunologiczne schorzenie charakteryzujące się nieprawidłową odpowiedzią układu immunologicznego na własne antygeny i rozwinięciem się procesu zapalnego wielu tkanek i narządów, między innymi nerek, stawów czy skóry. D. Oleksyn i wsp. wykazali, że w modelu mysim Sle (Sle1Sle3) wykorzystywanym do badań nad toczniem rumieniowatym specyficzny dla komórek B knockout Ripk4 (ang. B cell-specific PKK conditional knockout) skutkuje zmniejszeniem charakterystycznych dla tocznia symptomów takich jak powiększenie śledzio- ny, zwiększenie populacji komórek B czy spontaniczne tworzenie się ośrodków rozmnażania [33]. Zwiększenie ilości i dysfunkcja komórek B odgrywa ważną rolę w rozwoju chorób autoimmunologicznych ze względu na ich zdolność do produkcji autoprzeciwciał oraz cząsteczek regulujących odpowiedź immunologiczną takich jak cytokiny i chemokiny [34]. RIPK4 poprzez regulację szlaku NF-kB kontroluje transkrypcję białek z rodziny BCL2, których aktywność jest krytyczna dla przeżycia aktywnych komórek B. Obniżenie poziomu Ripk4 w komórkach B skutkuje zmniejszeniem odpowiedzi receptorów limfocytu B (BCR) receptorów TLR4 na stymulację anty-immuboglobuliną M (IgM) i lipopolisacharydem (LPS), co prowadzi do ograniczonej sygnalizacji na szlaku NFкB i zmniejszenia poziomu ekspresji białek antyapoptotycznych Bcl- $x_{L}$ i Bcl-2 [35]. W badaniach nad modelem Sle z knockoutem Ripk4 w komórkach B zaobserwowano również spadek poziomu przeciwciał IgG1, IgG2b, IgG2c oraz IgM, których wysoki poziom jest charakterystyczny dla modelu tocznia rumieniowatego [33].

Choroba zwyrodnieniowa stawów OA (łac. Osteoarthritis) jest chorobą przewlekłą rozwijającą się w wyniku działania czynników mechanicznych i biologicznych, które prowadzą do patologicznych zmian i degeneracji chrząstki stawowej oraz podchrzęstnej tkanki kostnej. Procesowi towarzyszy zwiększona produkcja czynników prozapalnych przez chondrocyty, które ulegają procesowi senescencji i w konsekwencji chronicznie utrzymujący się w obrębie stawu stan zapalny [36]. Proliferacja chondrocytów w tkankach dotkniętych zwyrodnieniową chorobą stawów jest niższa niż w przypadku tkanek zdrowych, natomiast poziom apoptozy jest znacznie wyższy. Kinaza RIPK4 jest regulatorem obu tych procesów. Badania grupy Zou i wsp. (2018) wykazały, że poziom ekspresji RIPK4 jest podwyższony $\mathrm{w}$ tkance dotkniętej OA w stosunku do zdrowych komórek, natomiast wyciszenie genu RIPK4 skutkuje wzrostem tempa proliferacji i zmniejszeniem poziomu apoptozy chondrocytów [37]. Regulacja tego procesu przez kinazę RIPK4 może zachodzić na drodze sygnalizacji przez szlak WNT/ $\beta$-katenina. Aktywność $\beta$-kateniny w chondrocytach sprzyja ich różnicowaniu i dojrzewaniu. $W$ modelu mysim wykazano, że aktywacja szlaku WNT/ $\beta$-katenina może prowadzić do wykształcenia się fenotypu podobnego do zwyrodnieniowej choroby stawów [38]. W tkankach dotkniętych OA obserwowany jest zwiększony poziom białek takich jak Wnt3a, $\beta$-katenina czy ufosforylowanej formy kinazy syntazy glikogenu $3 \beta$ (p-GSK-3 $\beta$ ), natomiast wyciszenie RIPK4 powoduje obniżenie ich poziomu. Ponadto poddanie komórek stymulacji agonistą szlaku WNT/ $\beta$-katenina odwraca efekt wyciszenia RIPK4 [37].

Zmieniony poziom RIPK4 obserwowany jest również w tkankach mięśniowych przy stwardnieniu zanikowym bocznym (łac. sclerosis lateralis amyotrophica). Schorzenie to objawia się degeneracją nerwów ruchowych i w konsekwencji zanikami mięśniowymi oraz postępującym paraliżem. Analiza mikromacierzy cDNA wykazała spadek ekspresji RIPK4 w tkance mięśni brzuchatych łydki myszy SOD $1^{\mathrm{G} 93 \mathrm{~A}} \mathrm{w}$ porównaniu do myszy typu dzikiego w okresie przed wystąpieniem pierwszych symptomów [39]. 


\section{RIPK4 A RAKI SKÓRY}

Raki skóry są u ludzi o fototypie 1-3 (wg. Fitzpatricka), popularnie zwanej rasą białą, jednym z najczęściej występujących nowotworów stanowiącym około 10\% wszystkich nowotworów złośliwych. Rak kolczystokomórkowy (SCC) (tac. carcinoma spinocellulare, ang. squamous cell carcinoma) stanowiący ok. $20 \%$ wszystkich raków skóry jest drugim co do częstości występowania, po raku podstawnokomórkowym (BCC) nowotworem skóry. SCC może się rozwijać z keratynocytów (warstwy kolczystej naskórka) lub przydatków skóry, szczególnie w obrębie odsłoniętych części ciała, a częstość występowania jest najwyższa $\mathrm{u}$ osób pracujących na wolnym powietrzu, jak również u ludzi często opalających się. Ważnym czynnikiem prognostycznym jest głębokość naciekania nowotworu oraz między innymi charakter stanu przednowotworowego, z którego rozwinął się. Zdolność do metastaz (tworzenie przerzutów) jest mniejsza w przypadku, gdy SCC rozwinął się w ognisku rogowacenia słonecznego w porównaniu do przypadku rozwoju raka na podłożu blizn owrzodzeń i przewlekłych stanów zapalnych skory. Rak kolczysto-komórkowy daje przerzuty u 2-3\% pacjentów [40]. Badania nad rolą RIPK4 w rakach skóry wykazały wyskoki poziom mutacji w SCC $[41,42]$. Co ciekawe, wg bazy Bioportal częstość mutacji w genie RIPK4 (domena kinazowa i powtórzeń ankirynowych) jest najwyższa w SCC (w 20\% przypadków) w porównaniu do innych nowotworów, np. dla czerniaka wynosi ok $6 \%$, jajnika $1 \%$, dla pozostałych < $1 \%[43,44]$. Zwiększony rozrost guzów SCC u myszy z indukowaną delecją Ripk4, a także niższy poziom ekspresji RIPK4 w SCC u ludzi w porównaniu do skóry zdrowej [26], sugeruje, że białko to w skórze może pełnić funkcję supresora nowotworów [10]. W celu zbadania czy brak Ripk4 sprzyja karcenogenezie Chen i wsp. stworzyli myszy z indukowaną delecją RIPK4 w keratynocytach (naskórku) RIPK4 ${ }^{\mathrm{EKO}}$. Skóra takich zwierząt charakteryzowała się grubszą warstwą naskórka, a keratynocyty zwiększonym poziomem białka TP63, jego lokalizacją jądrową a także spadkiem fosforylacji czynnika transkrypcyjnego NF-kB (p65). Następnie zwierzętom podano poprzez naskórną aplikację chemiczne kancerogeny: roztwory DMBA (7,12-dimethyl-1,2-benzanthracene) oraz PMA w acetonie w celu wywołania zmian nowotworowych i obserwowano pojawianie się SCC i brodawczaków (papilloma) przez 27 tygodni. Okazało się, że u myszy Ripk $4^{\mathrm{EKO}}$, brodawczaków było tyle samo, ale pojawiały się wcześniej i były większe niż u myszy typu dzikiego. Z kolei raki zaobserwowano $\mathrm{u}$ 9 myszy Ripk ${ }^{\mathrm{EKO}}$ już w 27 tygodniu trwania doświadczenia, natomiast u myszy typu dzikiego żadnego nawet po 54 tygodniach. Ponieważ nie zaobserwowano tworzenia się spontanicznych raków kolczystokomórkowych u myszy Ripk $4^{\mathrm{EKO}}$ naukowcy stwierdzili, że delecja RIPK4 nie wywołuje kancerogenezy, a jedynie sprzyja i promuje progresję nowotworów [45].

Do nowotworów skóry zaliczany jest również czerniak (łac. melanoma malignum) wywodzący się z stransformowanych melanocytów. Czerniak może rozwinąć się ze znamion barwnikowych powstających na skutek nieprawidłowości rozwojowych skory, które ujawniają się w różnym okresie życia, jak i de novo w prawidłowej skórze, błonie śluzowej czy błonie naczyniowej gałki ocznej. Należy do najbardziej złośliwych nowotworów [40]. Jak do tej pory nie ma doniesień na temat roli białka RIPK4 w czerniaku. Nasze nieopublikowane badania wskazują jednak na bardzo niski

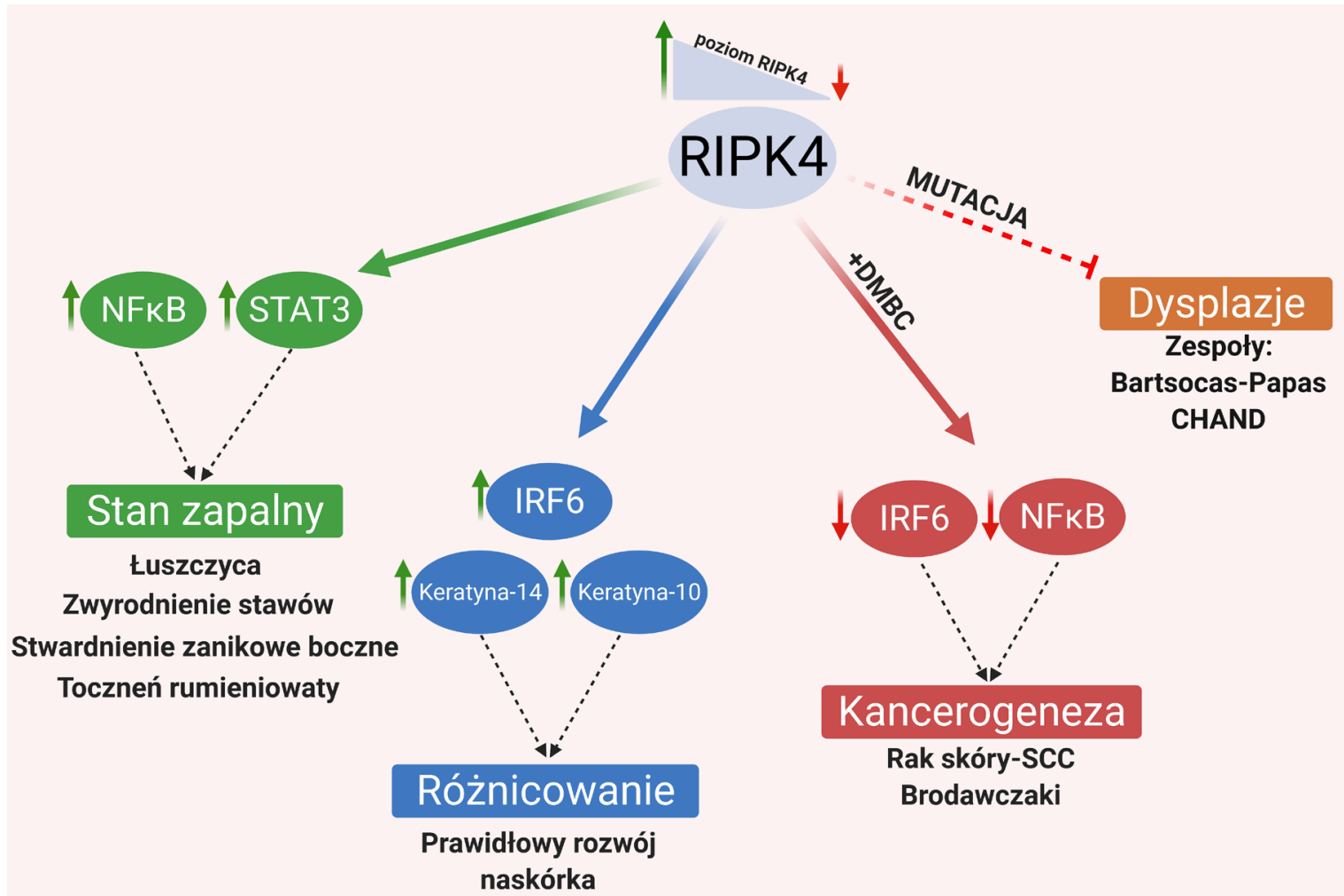

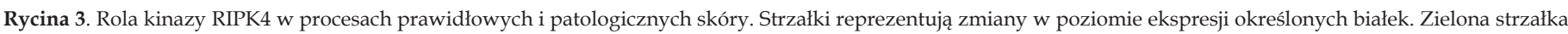

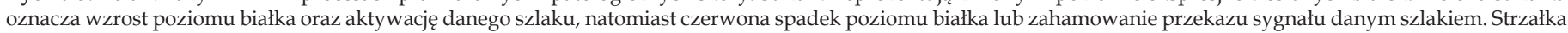
przerywana oznacza mutacje w genie kodującym RIPK4. 
poziom RIPK4 w prawidłowych melanocytach (względem keratynocytów).

\section{PODSUMOWANIE}

RIPK4 odrywa kluczową rolę w embriogenezie i homeostazie naskórka poprzez regulowanie procesu różnicowania się keratynocytów, a także w stanie zapalnym (Ryc. 3). Z punktu widzenia gojenia się ran stosowanie inhibitorów dla specyficznych RIPK4 mogłoby mieć zastosowanie praktyczne, jednak z uwagi na jej wykazaną rolę supresora nowotworów takie działanie mogłoby sprzyjać procesowi kancerogenezy. Ponadto ostatnimi czasy pojawia się wiele prac wskazujących na rolę onkogenną białka RIPK4, które wskazują na specyficzną i zależną od typu tkanki i nowotworu odmienną funkcję tego białka w różnych szlakach sygnałowych [10]. Pomimo wzrastającej wiedzy na temat mechanizmów funkcjonowania kinazy RIPK4 nie wiele wiadomo o fizjologicznych sygnałach regulujących tę kinazę. Poznanie mechanizmów prowadzących do aktywacji RIPK4 miałoby ogromną wartość w procesie zrozumienia funkcjonowania tej kinazy na poziomie biochemicznym oraz sposobu, w jaki kontroluje różnicowanie się naskórka czy proces nowotworzenia. Wiadomo, że kinaza PKC-1 $\beta$ konstytutywnie aktywuje RIPK4, który może być następnie degradowany w proteasomie na drodze zależnej od kompleksu SCF ${ }^{\beta-\operatorname{TrCP}}$ [46]. Kompleks ten podobnie jak kinaza RIPK4 pełni podwójną rolę $\mathrm{w}$ rozwoju i progresji nowotworów. Ze względu na wciąż niepełną wiedzę o kinazie RIPK4 i możliwościach jej zastosowania praktycznego, badania nad tym białkiem powinny być kontynuowane.

\section{PIŚMIENNICTWO}

1. Adams S, Munz B (2010) RIP4 is a target of multiple signal transduction pathways in keratinocytes: implications for epidermal differentiation and cutaneous wound repair. Exp Cell Res. 316:126-137

2. Cuny GD, Degterev A (2020) RIPK protein kinase family: Atypical lives of typical kinases. Semin Cell Dev Biol S1084-9521(19): 3024430247

3. Meylan E, Tschopp J (2005) The RIP kinases: crucial integrators of cellular stress. Trends Biochem Sci 30: 151-159

4. Zhang D, Lin J, Han J (2010) Receptor-interacting protein (RIP) kinase family. Cell Mol Immunol 7: 243-249

5. Damgaard RB, Nachbur U, Yabal M, Wong WW, Fiil BK, Kastirr M, Rieser E, Rickard JA, Bankovacki A, Peschel C, Ruland J, Bekker-Jensen S, Mailand N, Kaufmann T, Strasser A, Walczak H, Silke J, Jost PJ, Gyrd-Hansen M (2012) The ubiquitin ligase XIAP recruits LUBAC for NOD2 signaling in inflammation and innate immunity. Mol Cell 46: 746-758

6. Humphries F, Yang S, Wang B, Moynagh PN (2015) RIP kinases: key decision makers in cell death and innate immunity. Cell Death Differ 22: $225-236$

7. Huang CS, Oberbeck N, Hsiao YC, Liu P, Johnson AR, Dixit VM, Hymowitz SG (2018) Crystal Structure of Ripk4 Reveals DimerizationDependent Kinase Activity. Structure 26: 767-777.e5

8. Rideout HJ, Re DB (2017) LRRK2 and the "LRRKtosome" at the Crossroads of Programmed Cell Death: Clues from RIP Kinase Relatives. Adv Neurobiol 14: 193-208

9. De Groote P, Tran HT, Fransen M, Tanghe G, Urwyler C, De Craene B, Leurs K, Gilbert B, Van Imschoot G, De Rycke R, Guérin CJ, Holland P, Berx G, Vandenabeele P, Lippens S, Vleminckx K, Declercq W (2015) A novel RIPK4-IRF6 connection is required to prevent epithelial fusions characteristic for popliteal pterygium syndromes. Cell Death Differ 22: 1012-1024
10. Xu J, Wei Q, He Z (2020) Insight Into the Function of RIPK4 in Keratinocyte Differentiation and Carcinogenesis. Front Oncol 10:1562

11. Rountree RB, Willis CR, Dinh H, Blumberg H, Bailey K, Dean C Jr, Peschon JJ, Holland PM (2010) RIP4 regulates epidermal differentiation and cutaneous inflammation. J Invest Dermatol 130: 102-112

12. Urwyler-Rösselet C, Tanghe G, Leurs K, Gilbert B, De Rycke R, De Bruyne M, Lippens S, Bartunkova S, De Groote P, Niessen C, Haftek M, Vandenabeele P, Declercq W (2018) Keratinocyte-Specific Ablation of RIPK4 Allows Epidermal Cornification but Impairs Skin Barrier Formation. J Invest Dermatol 138: 1268-1278

13. Kim SW, Schifano M, Oleksyn D, Jordan CT, Ryan D, Insel R, Zhao J, Chen L (2014) Protein kinase C-associated kinase regulates NF-kB activation through inducing IKK activation. Int J Oncol 45: 1707-1714

14. Sümer C, Boz Er AB, Dinçer T (2019) Keratin 14 is a novel interaction partner of keratinocyte differentiation regulator: receptor-interacting protein kinase 4. Turk J Biol 43: 225-234

15. Lee P, Jiang S, Li Y, Yue J, Gou X, Chen SY, Zhao Y, Schober M, Tan M, Wu X (2017) Phosphorylation of Pkp1 by RIPK4 regulates epidermal differentiation and skin tumorigenesis. EMBO J. 36: 1963-1980

16. Kwa MQ, Huynh J, Aw J, Zhang L, Nguyen T, Reynolds EC, Sweet MJ, Hamilton JA, Scholz GM (2014) Receptor-interacting protein kinase 4 and interferon regulatory factor 6 function as a signaling axis to regulate keratinocyte differentiation. J Biol Chem 289: 31077-87

17. Oberbeck N, Pham VC, Webster JD, Reja R, Huang CS, Zhang Y, Roose-Girma M, Warming S, Li Q, Birnberg A, Wong W, Sandoval W, Kőmúves LG, Yu K, Dugger DL, Maltzman A, Newton K, Dixit VM (2019) The RIPK4-IRF6 signalling axis safeguards epidermal differentiation and barrier function. Nature 574: 249-53

18. Mitchell K, O'Sullivan J, Missero C, Blair E, Richardson R, Anderson B, Antonini D, Murray JC, Shanske AL, Schutte BC, Romano RA, Sinha S, Bhaskar SS, Black GC, Dixon J, Dixon MJ (2012) Exome sequence identifies RIPK4 as the Bartsocas-Papas syndrome locus. Am J Hum Genet 90: 69-75

19. Kalay E, Sezgin O, Chellappa V, Mutlu M, Morsy H, Kayserili H, Kreiger E, Cansu A, Toraman B, Abdalla EM, Aslan Y, Pillai S, Akarsu NA (2012) Mutations in RIPK4 cause the autosomal-recessive form of popliteal pterygium syndrome. Am J Hum Genet 90: 76-85

20. Busa T, Jeraiby M, Clémenson A, Manouvrier S, Granados V, Philip N, Touraine R (2017) Confirmation that RIPK4 mutations cause not only Bartsocas-Papas syndrome but also CHAND syndrome. Am J Med Genet A 173: 3114-3117

21. Online Mendelian Inheritance in Man 2021, dostęp 06.01.2021 https:/ / www.omim.org/entry/263650

22. Leslie EJ, O'Sullivan J, Cunningham ML, Singh A, Goudy SL, Ababneh F, Alsubaie L, Ch'ng GS, van der Laar IM, Hoogeboom AJ, Dunnwald M, Kapoor S, Jiramongkolchai P, Standley J, Manak JR, Murray JC, Dixon MJ (2015) Expanding the genetic and phenotypic spectrum of popliteal pterygium disorders. Am J Med Genet A 167A : 545-552

23. Chen L, Deng H, Cui H, Fang J, Zuo Z, Deng J, Li Y, Wang X, Zhao L (2018) Inflammatory responses and inflammation-associated diseases in organs. Oncotarget 9: 7204-7218

24. Sun SC (2011) Non-canonical NF-кB signaling pathway. Cell Research 21: $71-85$

25. Gong Y, Luo X, Yang J, Jiang Q, Liu Z (2018) RIPK4 promoted the tumorigenicity of nasopharyngeal carcinoma cells. Biomed Pharmacother 108: $1-6$

26. Poligone B, Gilmore ES, Alexander CV, Oleksyn D, Gillespie K, Zhao J, Ibrahim SF, Pentland AP, Brown MD, Chen L (2015) PKK suppresses tumor growth and is decreased in squamous cell carcinoma of the skin. J Invest Dermatol 135: 869-876

27. Hammouda MB, Ford AE, Liu Y, Zhang JY (2020) The JNK Signaling Pathway in Inflammatory Skin Disorders and Cancer. Cells 9: 857

28. Bae HC, Jeong SH, Kim JH, Lee H, Ryu WI, Kim MG, Son ED, Lee TR, Son SW (2018) RIP4 upregulates CCL20 expression through STAT3 signalling in cultured keratinocytes. Exp Dermatol 27: 1126-1133 
29. Kwa MQ, Scholz GM, Reynolds EC (2016) RIPK4 activates an IRF6-mediated proinflammatory cytokine response in keratinocytes. $\mathrm{Cy}$ tokine 83:19-26

30. Rodriguez J, Pilkington R, Garcia Munoz A, Nguyen LK, Rauch N, Kennedy S, Monsefi N, Herrero A, Taylor CT, von Kriegsheim A (2016) Substrate-Trapped Interactors of PHD3 and FIH Cluster in Distinct Signaling Pathways. Cell Rep 14: 2745-60

31. WHO Global report on psoriasis [Internet] (2016), dostęp: 06.01.2021 https://apps.who.int/iris/bitstream/handle/10665/204417/9789241565189_eng.pdf.psoriasis;jsessioni$\mathrm{d}=54912784 \mathrm{D} 28 \mathrm{C} 9 \mathrm{~F} 36 \mathrm{ECCD} 45471 \mathrm{AC5775B}$ ?sequence=1

32. Nestle FO, Kaplan DH, Barker J (2009) Psoriasis. N Engl J Med 361(5): 496-509

33. Oleksyn D, Zhao J, Vosoughi A, Zhao JC, Misra R, Pentland AP, Ryan D, Anolik J, Ritchlin C, Looney J, Anandarajah AP, Schwartz G, Calvi LM, Georger M, Mohan C, Sanz I, Chen L (2017) PKK deficiency in B cells prevents lupus development in Sle lupus mice. Immunol Lett 185: 1-11

34. Anolik JH (2013) B cell biology: implications for treatment of systemic lupus erythematosus. Lupus 22: 342-349

35. Chen L, Oleksyn D, Pulvino M, Sanz I, Ryan D, Ryan C, Lin CS, Poligone B, Pentland AP, Ritchlin C, Zhao J (2016) A critical role for the protein kinase PKK in the maintenance of recirculating mature $B$ cells and the development of B1 cells. Immunol Lett 172: 67-78

36. Collison J (2017) Removing old chondrocytes to combat disease. Nat Rev Rheumatol 13: 388

37. Zou L, Liu J, Lu H (2018) Influence of protein kinase RIPK4 expression on the apoptosis and proliferation of chondrocytes in osteoarthritis. Mol Med Rep 17: 3078-3084

38. Zhu M, Tang D, Wu Q, Hao S, Chen M, Xie C, Rosier RN, O'Keefe RJ, Zuscik M, Chen D (2009) Activation of beta-catenin signaling in particular chondrocytes leads to osteoarthritis-like phenotype in adult beta-catenin conditional activation mice. J Bone Miner Res 24: 12-21
39. de Oliveira GP, Maximino JR, Maschietto M, Zanoteli E, Puga RD, Lima L, Carraro DM, Chadi G (2014) Early gene expression changes in skeletal muscle from SOD1(G93A) amyotrophic lateral sclerosis animal model. Cell Mol Neurobiol 34: 451-462

40. Wolnicka-Głubisz A (2015) Zagrożenia związane z ekspozycją skóry na promieniowanie UV, W: M. Zmyślony i E.M. Nowosielska (red) Ochrona przed promieniowaniem jonizującym i niejonizującym Nowe uregulowania prawne, źródła, problemy pomiarowe. Wyd Wojskowa Akademia Techniczna, Warszawa, str.113-124

41. Li YY, Hanna GJ, Laga AC, Haddad RI, Lorch JH, Hammerman PS (2015) Genomic analysis of metastatic cutaneous squamous cell carcinoma. Clin Cancer Res 21: 1447-1456

42. Pickering CR, Zhou JH, Lee JJ, Drummond JA, Peng SA, Saade RE, Tsai KY, Curry JL, Tetzlaff MT, Lai SY, Yu J, Muzny DM, Doddapaneni $\mathrm{H}$, Shinbrot E, Covington KR, Zhang J, Seth S, Caulin C, Clayman GL, El-Naggar AK, Gibbs RA, Weber RS, Myers JN, Wheeler DA, Frederick MJ (2014) Mutational landscape of aggressive cutaneous squamous cell carcinoma. Clin Cancer Res 20: 6582-6592

43. cBio-portal 2021, dostęp 06.01.2021, https:/ / www.cbioportal.org

44. Lazar AD, Dinescu S, and Costache M (2020) Deciphering the molecular landscape of cutaneous squamous cell carcinoma for better diagnosis and treatment. J Clinical Medicine. $9: 2228$

45. Chen L, Hayden MS, Gilmore ES, Alexander-Savino C, Oleksyn D, Gillespie K, Zhao J, Poligone B (2018) PKK deletion in basal keratinocytes promotes tumorigenesis after chemical carcinogenesis. Carcinogenesis 39: 418-428

46. Tanghe G, Urwyler-Rösselet C, De Groote P, Dejardin E, De Bock PJ, Gevaert K, Vandenabeele P, Declercq W (2018) RIPK4 activity in keratinocytes is controlled by the $\mathrm{SCF}^{\beta-\operatorname{TrCP}}$ ubiquitin ligase to maintain cortical actin organization. Cell Mol Life Sci 75: 2827-2841

\section{The role of RIPK4 in epidermis physiology}

\section{Ewelina Madej, Anna Lisek, Agnieszka Wolnicka-Głubisz ${ }^{\varpi}$}

Department of Biophysics, Faculty of Biotechnology, Biophysics and Biotechnology, Jagiellonian University in Krakow

$\square_{\text {corresponding author: a.wolnicka-glubisz@uj.edu.pl }}$

Key words: RIPK4, epidermis, differentiation, inflammation

\section{ABSTRACT}

Proteins which regulate morphogenesis of the epidermis ensure its proper construction and function and mutations or abnormal expression of those proteins impact epidermal function. One recently described protein is Receptor Interacting Serine/Threonine Kinase 4 (RIPK4). Mutations in RIPK4 cause the autosomal-recessive form of Bartsocas-Papas syndrome and Popliteal Pterygium Syndrome the Aslan type. In mice, deletion of Ripk4 (Ripk4--) leads to premature death of neonates caused by numerous skin adhesions. RIPK4 regulates development and maintenance of differentiation and proliferation homeostasis of keratinocytes, as well as inflammation. RIPK4 also appears to act as a tumor suppressor in skin, since expression is decreased in squamous skin carcinoma and inducible deletion in mice facilitates induction and growth of papillomas and squamous skin carcinomas in chemical carcinogenesis. The review describes the RIP family, the engagement of RIPK4 in differentiation of the epidermis and consequences resulting from its improper expression. 